\title{
Pengaruh Teknologi Informasi dan E-Commerce terhadap Perdagangan Indonesia ke Negara ASEAN
}

\author{
Yulya Aryani ${ }^{\mathrm{a}, *}$, Wina Andari ${ }^{\mathrm{a}}$, \& Suhindarto ${ }^{\mathrm{a}}$ \\ ${ }^{a}$ Pusat Kajian Perekonomian (PKP), Sekretariat Kementerian Koordinator Bidang Perekonomian
}

\begin{abstract}
This paper aims to confirm the impact of ICT and e-commerce on Indonesia's trade to ASEAN partner countries. The analytical method used in this research is a qualitative and quantitative approach to panel data using a gravity model. Time series used in this research are from 2010 to 2018 with the cross section of nine ASEAN member countries. The results of the analysis shows that the increasing of ICT adoption (internet users in Indonesia and broadband services in trading partner countries) and the use of e-commerce (B2B transaction in trading partner countries) has proven to increase Indonesia's trade in ASEAN market. In addition, the economic growth of Indonesia, market share of Indonesia, and economic distance also have an impact on increasing Indonesia's trade in ASEAN market.
\end{abstract}

Keywords: ASEAN; E-commerce; ICT adoption; Gravity Model

\begin{abstract}
Abstrak
Penelitian ini bertujuan mengonfirmasi dampak ICT dan e-commerce pada perdagangan Indonesia ke negara mitra ASEAN. Metode analisis yang digunakan yaitu pendekatan kualitatif dan kuantitatif data panel menggunakan gravity model. Data runut waktu dimulai dari tahun 2010 hingga 2018 dengan cross section sembilan negara anggota ASEAN. Hasil analisis menunjukkan bahwa peningkatan adopsi ICT (internet users di Indonesia dan layanan broadband di negara mitra) serta pemanfaatan e-commerce (transaksi B2B di negara mitra) terbukti meningkatkan perdagangan Indonesia di pasar ASEAN. Di samping itu, pertumbuhan ekonomi Indonesia, pangsa pasar Indonesia, dan jarak ekonomi juga berdampak pada peningkatan nilai perdagangan Indonesia di pasar ASEAN.
\end{abstract}

Kata Kunci: adopsi teknologi informasi; perdagangan di ASEAN; e-commerce; Model Gravity

Klasifikasi JEL: F10; O14; O38

*Alamat Penulis Korespondensi: Kementerian Koordinator Bidang Perekonomian, Gedung Ali Wardana Lt 5, Jalan Lapangan Banteng Timur No 2-4, Jakarta Pusat. 10710. E-mail: yulya_y.i@ekon.go. id. 


\section{Pendahuluan}

Tren perkembangan teknologi yang terjadi secara masif telah mengarah pada revolusi industri keempat yang menekankan pada pemanfaatan teknologi informasi dan komunikasi sebagai basis dalam berbagai bidang, termasuk ekonomi. Teknologi informasi dan komunikasi (information and communications technolo$g y / \mathrm{ICT}$ ) dimanfaatkan sepenuhnya tidak hanya dalam proses produksi tetapi juga di seluruh rantai industri, dan kemudian melahirkan model bisnis baru. Pada level makro, perkembangan teknologi mendorong pembangunan ekonomi dan memberikan kontribusi pada pertumbuhan ekonomi suatu negara (Arsyad, 1999; Cette et al., 2005; Choi \& Yi, 2009) dengan turut mendorong produktivitas dan efisiensi serta menciptakan kompetisi dalam perdagangan (Choi \& Yi, 2009).

ASEAN adalah salah satu wilayah dengan potensi besar sebagai kekuatan ekonomi dunia. Hal ini disebabkan karena ASEAN memiliki populasi yang mencapai 8,5\% dari populasi dunia dan mampu menyumbangkan 3,5\% dari PDB (Pendapatan Domestik Bruto) dunia di tahun 2017. Dari sisi perdagangan, pada tahun 2017 perdagangan barang di ASEAN tumbuh 15\% dan perdagangan jasa tumbuh $6,1 \%$. Sebagaimana yang ditunjukkan pada Gambar 1, mitra dagang eksternal utama ASEAN selama tahun 2017 adalah Tiongkok dengan total nilai USD441,6 miliar (17,1\%), Uni Eropa dengan total nilai USD261,3 miliar (10,1\%), dan Amerika Serikat dengan total nilai USD235 miliar (9,1\%). Perdagangan IntraASEAN merupakan pangsa terbesar perdagangan ASEAN, yaitu sebesar 22,9\% atau setara dengan nilai USD590,4 miliar.

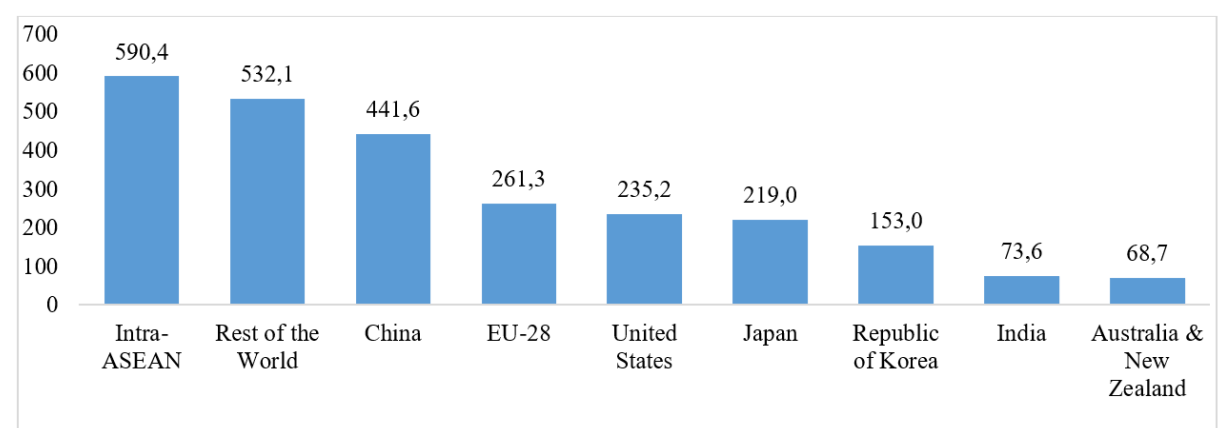

Gambar 1: Perdagangan Barang di ASEAN pada Tahun 2017 (USD miliar) Sumber: ASEAN Secretariat (2018)

Di samping itu, negara-negara ASEAN saat ini telah terkoneksi secara online dan menikmati layanan tersebut salah satunya melalui telepon seluler. Hal ini terlihat dari Gambar 2, dimana jumlah pengguna internet di ASEAN secara ratarata mencapai 56,5\% dengan jumlah pengguna internet tertinggi pada negara Brunei (86\%) dan Singapura (83\%). Penggunaan telepon seluler tersebut juga sangat aktif digunakan dimana pada tahun 2017 tercatat hampir semua warga 
negara di ASEAN memiliki telepon seluler lebih dari satu (angka di atas 100\%), kecuali Laos dan Myanmar. Secara rata-rata, penggunaan telepon seluler di ASEAN pada tahun 2017 mencapai 128,8\%.

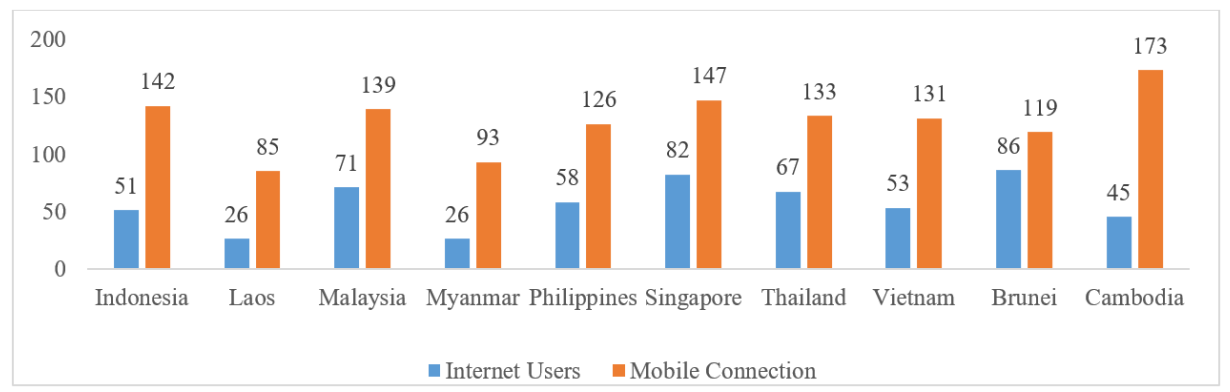

Gambar 2: Tingkat Penggunaan ICT di Negara ASEAN Tahun 2017 (\%) Sumber: Kemp (2017)

Bankole et al. (2015) dan Chu dan Guo (2019) menjelaskan bahwa kemajuan penggunaan ICT memegang peranan penting dalam memfasilitasi perdagangan. Dengan lebih dari 339 juta jiwa pengguna internet dan tingkat penetrasi yang mencapai 53\% di tahun 2017, turut menjadikan ASEAN sebagai negara ketiga terbesar pengguna internet di Asia, setelah Tiongkok dan India (Sen et al., 2016). Berbagai studi menyatakan bahwa penetrasi internet mendorong perdagangan internasional suatu negara yang kemudian mendorong pertumbuhan ekonomi.

Infrastruktur ICT yang terus berkembang disertai bonus demografi yang melek teknologi dapat menjadi faktor pendorong utama pertumbuhan ekonomi ASEAN. Studi yang dilakukan oleh Xing (2018), Chu dan Guo (2019), dan Ozcan (2018) menunjukkan bahwa pemanfaatan ICT dalam perdagangan menawarkan beberapa manfaat seperti (i) integrasi pasar dan industri dengan transaksi, distribusi barang dan jasa tidak mengenal batas waktu dan geografis; (ii) efisiensi biaya perdagangan; dan (iii) membuka dan memperluas akses pasar; serta (iv) mengakselerasi aktivitas bisnis dalam pasar intra-ASEAN dan global. Lebih jauh revolusi ICT dengan digitalisasi mendorong terciptanya perdagangan berbasis elektronik (e-commerce). E-commerce terus mengalami pertumbuhan yang cepat dalam dunia perdagangan, karena memiliki pengaruh yang cukup signifikan yang tampak dari kuantitas transaksi melalui sarana ini, baik yang dilakukan secara business to business (B2B) maupun business to consumer (B2C) atau pemanfaatan dalam bentuk lainnya. Studi Google Temasek pada tahun 2017 (Anandan et al., 2017) menyebutkan bahwa pasar e-commerce di ASEAN akan mencapai USD200 miliar tahun pada 2025 dengan pertumbuhan compound annual growth rate (CAGR) sebesar 32\%. Perdagangan B2C di ASEAN mengalami perkembangan pesat dengan CAGR dari 5 negara ASEAN (Singapura, Malaysia, Thailand, Indonesia, dan Vietnam) diproyeksikan tumbuh sebesar 37\% dari USD7 miliar tahun 2013 menjadi USD34,5 miliar pada tahun 2018. 
Guna mengoptimalkan potensi pasar, dalam ASEAN ICT Masterplan 2020 (ASEAN Secretariat, 2015) negara anggota ASEAN telah menyepakati bahwa perekonomian ASEAN didorong melalui keterlibatan dalam ekonomi digital dan e-commerce. Untuk itu, negara-negara ASEAN menjalankan beberapa program unggulan pengembangan ICT seperti peningkatan konektivitas digital yang bertujuan meminimalisir hambatan dan meningkatkan akses masyarakat dalam e-commerce. Lebih jauh, pada tahun 2018 negara-negara ASEAN sepakat membentuk ASEAN Coordinating Committee on Electronic Commerce yang bertujuan untuk menjembatani kebutuhan lintas batas perdagangan e-commerce dalam meningkatkan pertumbuhan ekonomi di ASEAN.

Di tengah gencarnya penerapan ICT dalam menstimulus perdagangan, ekonomi digital memberikan kontribusi yang signifikan terhadap pertumbuhan ekonomi Indonesia. Hal ini didukung oleh fakta-fakta penelitian mengenai dampak positif ICT terhadap pembangunan dan pertumbuhan ekonomi, jika penetrasi internet sebesar 10\% menyebabkan kenaikan 1,3\% PDB atau dengan tingkat penggunaan internet sebesar 21,5\% sama dengan kenaikan 10\% PDB per kapita (Andrés et al., 2010; Choi \& Yi, 2009). Pada tataran ASEAN, Indonesia merupakan pasar e-commerce terbesar. Studi Google Temasek pada tahun 2018 (Anandan et al., 2018) menunjukkan bahwa ekonomi digital Indonesia mencapai USD27 miliar atau sekitar IDR391 triliun. Angka tersebut menjadikan transaksi ekonomi digital Indonesia berada di peringkat pertama untuk kawasan Asia Tenggara dengan kontribusi sebesar 49\%. Bonus demografi dan infrastruktur telekomunikasi yang terus berkembang dengan penetrasi internet yang meningkat (mencapai 68,4\% di tahun 2018) menyebabkan kontribusi sektor ini terhadap ekonomi Indonesia berpotensi terus meningkat.

Studi mengenai dampak ICT dan perkembangan e-commerce telah banyak dilakukan sebagaimana yang telah dijelaskan sebelumnya. Beberapa penelitian fokus mengeksplorasi dampak ICT terhadap perdagangan di pasar negara mitra ASEAN serta pemanfaatan $e$-commerce dalam mendorong aktivitas perdagangan, namun belum terdapat penelitian yang menggambarkan dampak ICT dan pemanfaatan e-commerce dengan mengoptimalkan pasar sendiri yaitu intra-ASEAN. Untuk itu, penelitian ini bermaksud untuk mengkaji lebih lanjut terkait interaksi perdagangan antara Indonesia dan negara-negara ASEAN sehingga mendapatkan pemahaman yang menyeluruh mengenai dampak dari perkembangan ICT dan pemanfaatan e-commerce terhadap peningkatan perdagangan Indonesia pada negara-negara ASEAN. Bagian kedua dari paper ini menyajikan tinjauan pustaka terhadap penelitian sebelumnya yang mengkaji dampak ICT dan e-commerce terhadap perdagangan internasional. Selanjutnya pada bagian ketiga dijelaskan data dan metodologi yang digunakan dalam melakukan analisis. Bagian keempat mengulas hasil dan pembahasan, sementara bagian kelima menyajikan simpulan dan saran yang menjadi penutup dari tulisan ini. 


\section{Tinjauan Pustaka}

Studi yang dilakukan oleh Xing (2018) meneliti tentang bagaimana pengaruh ICT dan e-commerce pada sistem pedagangan bilateral. Studi ini menggunakan dua kelompok variabel yaitu variabel makroekonomi dan variabel ICT. Hasil studi tersebut menunjukkan bahwa pangsa pasar, PDB, contagious (inter- aksi dari negara yang bersebelahan), jarak ekonomi, dan jumlah penggunan internet serta e-commerce berpengaruh signifikan dalam mendorong perdagangan bilateral tersebut. Secara rinci hasil studi tersebut, adalah sebagai berikut:

- Pangsa pasar atau ukuran pasar relatif dari negara pengekspor dan pengimpor merupakan indikator penting yang berperan dalam menjelaskan variasi perdagangan di antara negara-negara tersebut. Selain itu, sebagai proksi dari daya beli, PDB per kapita nominal berpengaruh positif signifikan pada perdagangan bilateral. Sehingga, semakin tinggi daya beli akan berdampak pada peningkatan jumlah permintaan dan semakin besarnya pangsa pasar suatu negara akan berpengaruh pada tingginya aktivitas penawaran.

- Variabel contagious atau variabel yang mengukur interaksi dari negara yang saling bersebelahan memiliki hasil yang tidak signifikan dalam mempengaruhi perdagangan. Hal ini dimungkinkan karena akses pasar, perjanjian yang mengenakan halangan tarif dan non-tarif menjadi semakin rumit dan menyebabkan masalah bukan hanya di faktor perbatasan saja. Kemudian variabel bahasa dan colony memiliki pengaruh yang signifikan dan positif, yang berarti negara yang memiliki bahasa yang menyerupai dan keterikatan politik secara kolonial akan meningkatkan arus perdagangan antar negara yang berdagang.

- Jarak ekonomi berpengaruh negatif signifikan. Hal ini menggindikasikan bahwa semakin jauh jarak geografis berdampak pada semakin lamanya waktu pengiriman yang diperlukan sehingga akan mengurangi intensitas perdagangan. Selain itu, digunakan juga indikator lain yaitu biaya pengiriman dimana memiliki hubungan negatif dan signifikan.

- Penerapan ICT dalam sistem perdagangan terbukti memiliki pengaruh positif signifikan. ICT berperan dalam meningkatkan komunikasi antar negara yang melakukan perdagangan. Selain itu, akses internet dengan kecepatan tinggi dan tersedianya server yang aman juga terbukti dalam memperlancar aktivitas perdagangan.

- Penggunaan e-commerce juga signifikan berdampak pada peningkatan aktivitas perdagangan. Melalui e-commerce, baik individu ataupun perusahaan dapat mencari sumber barang atau jasa (produsen) dan menjual produk yang dimiliki dengan lebih efisien tanpa ada kendala waktu dan jarak.

Kemudian Chu dan Guo (2019) melakukan studi yang lebih rinci dengan meneliti pengaruh penerapan ICT pada aktivitas perdagangan Tiongkok-ASEAN. Studi tersebut menyimpulkan dua hal yaitu pertama, ICT berdampak positif dan signifikan terhadap perdagangan internasional antara Tiongkok-ASEAN. Ke$d u a$, penggunaan internet memberikan dampak positif dalam kegiatan ekspor 
Tiongkok-ASEAN, lebih besar daripada telepon dan telepon seluler. Di sisi lain, pada aktivitas impor Tiongkok-ASEAN, penggunaan internet dan telepon seluler memiliki pengaruh yang positif. Hal tersebut menggambarkan bahwa penggunaan ICT dalam aktivitas perdagangan memengang peranan penting.

Selain itu, Ozcan (2018) juga meneliti bagaimana pengaruh ICT dalam perdagangan internasional negara Turki dengan menggunakan gravity model. Ozcan menyimpulkan bahwa IDI (ICT Development Index) memiliki pengaruh positif signifikan terhadap peningkatan volume ekspor dan impor pada perdagangan bilateral Turki. Penerapan ICT berperan dalam mengurangi biaya perdagangan, seperti fixed-market entry cost, communication and information cost. Semakin tinggi tingkat adopsi ICT antara kedua negara pararel dengan meningkatnya aktivitas perdagangan bilateral di antara mereka. Secara keseluruhan, ICT memiliki dampak positif dan signifikan pada volume ekspor dan impor Turki, namun dampaknya lebih besar pada impor daripada ekspor. Ini membuktikan bahwa ketersediaan akses internet dan penggunaan ICT yang handal menjadi faktor krusial dalam meningkatkan volume ekspor.

Studi tersebut juga menunjukkan bahwa PDB berpengaruh positif signifikan terhadap kegiatan ekspor dan impor (perdagangan bilateral) Turki. Dengan pendekatan gravity model, studi tersebut mengkonfimasi bahwa ukuran ekonomi dari negara mitra dan jarak geografis menjadi faktor penting dalam mendorong aktivitas perdagangan. Penelitian tersebut juga menggunakan populasi sebagai indikator ukuran negara dan memberikan hasil yang menarik. Populasi dapat meningkatkan penawaran pekerja dan juga mendorong peningkatan aktivitas produksi di domestik sehingga berdampak pada peningkatan ekspor. Di sisi lain, peningkatan populasi juga berimplikasi pada tingginya pemintaan barang dan jasa sehingga mendorong aktivitas impor.

\section{Metode}

\subsection{Jenis dan Sumber Data}

Jenis data yang digunakan adalah data sekunder dengan periode tahun 2010-2018. Negara yang diteliti merupakan negara anggota ASEAN mitra dagang Indonesia yang terdiri dari Brunei Darussalam, Kamboja, Laos, Malaysia, Myanmar, Filipina, Singapura, Thailand, dan Vietnam. Data yang digunakan berasal dari berbagai sumber, yaitu World Bank, World Development Indicators (WDI), World Economic Forum (WEF), dan International Monetary Fund (IMF).

\subsection{Metode Analis Data}

Metode analisis yang digunakan adalah analisis kuantitatif data panel statis dengan pendekatan gravity model. Gravity model digunakan untuk menjelaskan aliran perdagangan bilateral dengan membagi ukuran ekonomi antara dua negara yang direpresentasikan dengan PDB dan jarak antara pusat perdagangan 
antara kedua negara (Bergstrand \& Egger, 2013). Menurut Burger et al. (2009), persamaan gravity model adalah sebagai berikut:

$$
\text { trade }_{i j}=A \frac{\left(G D P_{i}\right)^{b 1}\left(G D P_{j}\right)^{b 2}}{\left(\text { distance }_{i j}\right)^{b 3}}
$$

Dimana trade $_{i j}$ menunjukkan nilai perdagangan antara negara $i$ dan $j, G D P_{i}$ menunjukkan pendapatan nasional negara $i, G D P_{j}$ menunjukkan pendapatan

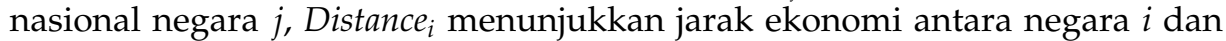
$j$, dan $A$ menunjukkan konstanta. Rumus tersebut menunjukkan bahwa nilai perdagangan secara positif dipengaruhi oleh pendapatan nasional negara asal dan pendapatan nasional negara tujuan, dan secara negatif dipengaruhi oleh jarak ekonomi antara negara asal dan negara tujuan.

Untuk menganalisis pengaruh ICT dan e-commerce terhadap perdagangan Indonesia ke negara anggota ASEAN, digunakan beberapa variabel yang didasarkan pada penelitian terdahulu dengan membagi menjadi tiga kelompok variabel, yaitu makroekonomi, ICT, dan e-commerce. Perbedaan dengan penelitian terdahulu antara lain adalah data pengamatan yang digunakan selama 2010 sampai 2018 dan penelitian ini spesifik membahas interaksi perdagangan Indonesia dengan mitra negara anggota ASEAN. Model yang digunakan pada analisis ini dirumuskan sebagai berikut:

$$
\begin{aligned}
\text { EXPORT }_{i j t}= & \beta_{0}+\beta_{1} \text { MARKETSIZE }_{i j t}+\beta_{2} \text { GDP }_{i t}+\beta_{3} \text { GDP }_{j t}+\beta_{4} \text { DISTANCE }_{i j t} \\
& +\beta_{5} \text { INTERNETUSER }_{i t}+\beta_{6} \text { INTERNETUSER }_{j t} \\
& +\beta_{7} \text { BROADBAND }_{i t}+\beta_{8} \text { BROADBAND }_{j t}+\beta_{9} \text { CELLPHONE }_{i t} \\
& +\beta_{10} \text { CELLPHONE }_{j t}+\beta_{11} \text { B }_{2} B_{i t}+\beta_{12}{\text { B } 2 B_{j t}+\varepsilon_{i t}}
\end{aligned}
$$

dimana:

EXPORT $_{i j t}$ : Nilai ekspor total Indonesia ke negara mitra ASEAN (juta USD) MARKETSIZE $E_{i j}$ : Pangsa pasar Indonesia di negara mitra ASEAN (\%)

$G D P_{i t}:$ Pertumbuhan PDB Indonesia (\%)

$G D P_{j t}$ : Pertumbuhan PDB negara mitra ASEAN (\%)

DISTANCE $E_{i j t}$ : Jarak ekonomi Indonesia ke negara mitra ASEAN (km)

INTERNETUSER it $_{\text {: }}$ Tingkat pengguna internet di Indonesia (\%)

INTERNETUSER $j t$ : Tingkat pengguna internet di negara mitra ASEAN (\%)

$B R O A D B A N D_{i t}$ : Jumlah pelanggan jaringan telekomunikasi per 100 orang di Indonesia

$B R O A D B A N D_{j t}:$ Jumlah pelanggan jaringan telekomunikasi per 100 orang di negara mitra ASEAN

CELLPHONE $_{i t}$ : Jumlah pelanggan seluler per 100 orang di Indonesia

CELLPHONE $_{j t}$ : Jumlah pelanggan seluler per 100 orang di negara mitra ASEAN $B 2 B_{i t}$ : Indeks tingkat penggunaan internet pada transaksi business to business di Indonesia 
$B 2 B_{j t}$ : Indeks tingkat penggunaan internet pada transaksi business to business di negara mitra ASEAN

$\varepsilon_{\text {it }}:$ Error

Berdasarkan latar belakang dan tinjauan pustaka yang dilakukan, variabel bebas yang digunakan dalam penelitian ini diduga memiliki pengaruh terhadap perdagangan. Variabel makroekonomi yaitu pertama, pangsa pasar Indonesia menggambarkan ukuran pasar negara pengekspor dan kedua, variabel pertumbuhan PDB menggambarkan kekuatan pasar negara pengeskpor maupun pengimpor, memiliki pengaruh positif terhadap ekspor. Ketiga, variabel jarak ekonomi yang menggambarkan waktu dan biaya perdagangan memiliki pengaruh terhadap ekspor Indonesia secara negatif. Selanjutnya, variabel ICT yang terdiri dari jumlah pengguna internet, jumlah pelanggan jaringan telekomunikasi, dan jumlah pelanggan telepon seluler memiliki pengaruh terhadap ekspor Indonesia secara positif. Adapun variabel e-commerce, yaitu penggunaan internet pada transaksi B2B juga memiliki pengaruh terhadap ekspor Indonesia secara positif.

\section{Hasil dan Pembahasan}

\subsection{Analisis Eksploratif Data}

Gambaran umum mengenai statistik deskriptif variabel utama yang digunakan dalam penelitian tahun 2010 hingga 2018 sebagaimana ditunjukkan oleh Tabel 1. Internet users merupakan variabel yang menunjukkan tingkat pengguna internet di Indonesia dan mitra di ASEAN. Dari tahun 2010-2018 pengguna internet terus mengalami peningkatan dengan rata-rata selama periode tersebut adalah sebesar 19,36\% di Indonesia dan 46,29\% di ASEAN, walaupun tingkat pengguna internet di Indonesia masih lebih kecil daripada di wilayah ASEAN. Sejalan dengan peningkatan pengguna internet, broadband yang merupakan indikator jaringan internet dengan kecepatan tinggi juga mengalami peningkatan kualitas khususnya di negara-negara mitra Indonesia di ASEAN. Hal ini terlihat dari

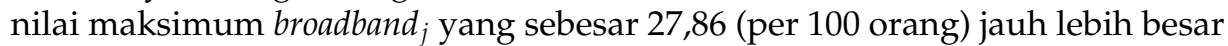
dari Indonesia. Data ini juga menggambarkan bahwa kualitas jaringan internet kecepatan tinggi di Indonesia masih jauh tertinggal dari pada negara-negara mitra di ASEAN.

Di sisi lain, jumlah penggunaan cellphone atau telepon seluler, baik di Indonesia dan di negara-negara mitra ASEAN juga mengalami peningkatan dengan nilai rata-rata dari kepemilikan telepon seluler tersebut tidak terlalu berbeda baik di Indonesia dan negara anggota ASEAN lainnya. Hal ini mengindikasikan bahwa masyarakat Indonesia selama periode penelitian umumnya telah memiliki telepon seluler sejalan dengan perkembangan kepemilikan di negara lain. Hal yang menarik juga ditunjukkan dari data B2B yang menggambarkan tingkat penetrasi kegiatan e-commerce. Selama periode tersebut kegiatan e-commerce di Indonesia hampir sama dengan wilayah ASEAN dan hal tersebut mengindikasikan bahwa secara umum masyarakat Indonesia sangat aktif melakukan kegiatan 
Tabel 1: Statistik Deskriptif Variabel Penelitian Periode 2010-2018

\begin{tabular}{lrrrr}
\hline Variabel & Rata-Rata & Standar Deviasi & Nilai Maksimum & Nilai Minimun \\
\hline InternetUser $_{i}$ & 19,362090 & 4,013265 & 25,450000 & 14,520000 \\
InternetUser $_{j}$ & 46,287300 & 23,399030 & 84,450000 & 6,800000 \\
Broadband $_{i}$ & 1,496824 & 0,263107 & 2,001947 & 1,198554 \\
Broadband $_{j}$ & 7,733773 & 8,719667 & 27,857590 & 0,062822 \\
Cellphone $_{i}$ & 130,897900 & 8,815719 & 147,660000 & 113,290000 \\
Cellphone $_{j}$ & 123,741700 & 28,787650 & 157,402700 & 55,930080 \\
B2B $_{i}$ & 4,882143 & 0,186694 & 5,100000 & 4,600000 \\
B2B $_{j}$ & 5,035714 & 0,675066 & 6,000000 & 3,300000 \\
\hline
\end{tabular}

Sumber: Output Eviews 11

penawaran dan/atau pembelian barang dan jasa melalui e-commerce.

\subsection{Analisis Hasil Pengolahan Data}

Tabel 2 menyajikan hasil estimasi faktor-faktor yang memengaruhi kinerja perdagangan (Export ${ }_{i j}$ ) Indonesia di ASEAN dengan menggunakan metode Fixed Effect Model. Penggunaan model tersebut didasarkan atas hasil pemilihan model terbaik melalui uji Chow dan Hausman. Dari hasil pengujian diperoleh nilai $P$-value $(0,0001)<$ taraf nyata $5 \%$, hal ini menunjukkan bahwa cukup bukti untuk menolak $H_{0}$, yaitu menggunakan Pooled Least Square sehingga model yang digunakan adalah Fixed Effect Model. Berdasarkan hasil uji Hausman diperoleh nilai $P$-value $(0,0000)<$ taraf nyata 5\% maka H0 (menggunakan Random Effect Model) ditolak. Selain itu, pada hasil estimasi terpilih juga telah dilakukan uji asumsi klasik agar mendapatkan model regresi yang terbebas dari masalah-masalah seperti multikolinearitas (nilai korelasi peubah bebas $\leq 0,8$ ), normalitas (nilai probabilitas Jarque Bera $>$ 0,05), dan autokorelasi (nilai DW 3,083591), serta heteroskedastisitas (sum square resid unweighted > sum square resid weighted) telah diatasi dengan melakukan pembobotan cross section weight dan period weight (Prasanti et al., 2015; Sutikno et al., 2017).

Tabel 2: Hasil Uji Chow dan Hausman

\begin{tabular}{lccc}
\hline & \multicolumn{3}{c}{ Probabilitas Chi-Sq } \\
\cline { 2 - 4 } & Uji Chow & Uji Hausman & Pendekatan \\
\hline Model penelitian & 0,0001 & 0,0000 & FEM \\
\hline Sumber: Output Eviews 11 & &
\end{tabular}

Hasil estimasi terhadap faktor-faktor yang memengaruhi kinerja perdagangan $\left(\right.$ Export $\left._{i j}\right)$ Indonesia di ASEAN secara lengkap ditunjukkan pada Tabel 3. Berdasarkan hasil estimasi tersebut, internet users dan broadband yang merupakan proksi dari ICT, transaksi B2B sebagai proksi dari kegiatan e-commerce, serta pangsa pasar, jarak ekonomi, dan pertumbuhan PDB sebagai proksi dari kondisi makroekonomi terbukti memengaruhi kinerja perdagangan Indonesia dengan negara-negara mitra di kawasan ASEAN. 
Tabel 3: Hasil Estimasi Fixed Effect Model

\begin{tabular}{|c|c|c|c|c|}
\hline \multirow{2}{*}{ Variabel Independen } & \multicolumn{4}{|c|}{ Variabel Dependen: Export ${ }_{i j}$} \\
\hline & [1] & {$[2]$} & [3] & [4] \\
\hline InternetUser ${ }_{i}$ & $\begin{array}{c}-28,51757 \\
(-2,017042)\end{array}$ & $\begin{array}{l}3738,473^{* *} \\
(2,378135)\end{array}$ & & $\begin{array}{l}582,2812^{* *} \\
(3475770)\end{array}$ \\
\hline Internet User $_{j}$ & $\begin{array}{c}26,20788^{* * * *} \\
(4,116114)\end{array}$ & $\begin{array}{c}57,61856 \\
(1,433851)\end{array}$ & & $\begin{array}{c}28,85539 \\
(0,5960)\end{array}$ \\
\hline Broadband $_{i}$ & $\begin{array}{l}615,0133^{*} \\
(1,731701)\end{array}$ & $\begin{array}{c}-84541,33^{* *} \\
(-2,447695)\end{array}$ & $\begin{array}{c}857,3005 \\
(0,2999067)\end{array}$ & $\begin{array}{r}-17580,00^{* * *} \\
(-5,277063)\end{array}$ \\
\hline Broadband $_{j}$ & $\begin{array}{c}173,6572^{* * *} \\
(11,23052)\end{array}$ & $\begin{array}{c}1160,112^{* * *} \\
(4,406914)\end{array}$ & $\begin{array}{c}702,8650^{* * *} \\
(6,187250)\end{array}$ & $\begin{array}{c}1006,310^{* * *} \\
(4,947912)\end{array}$ \\
\hline Cellphone $_{i}$ & $\begin{array}{c}3,702132 \\
(0,949620)\end{array}$ & $\begin{array}{l}1191,553^{* * *} \\
(2,343939)\end{array}$ & $\begin{array}{c}-140,5964 \\
(-1,789590)\end{array}$ & \\
\hline Cellphone $_{j}$ & $\begin{array}{l}3,950694^{* *} \\
(1,927156)\end{array}$ & $\begin{array}{c}13,45901 \\
(0,417086)\end{array}$ & $\begin{array}{l}27,56886^{*} \\
(1,834858)\end{array}$ & \\
\hline$B 2 B_{i}$ & & $\begin{array}{l}-31324,73^{* *} \\
(-2,650679)\end{array}$ & & \\
\hline$B 2 B_{j}$ & & $\begin{array}{c}-935,2871 \\
(-1,063173)\end{array}$ & $\begin{array}{l}1124,339^{* *} \\
(2,153446)\end{array}$ & $\begin{array}{c}1908,714^{* * *} \\
(3,932292)\end{array}$ \\
\hline MarketSize $_{i j}$ & & & $\begin{array}{c}1679,740^{* * *} \\
(3,161038)\end{array}$ & $\begin{array}{c}1947,250^{* * *} \\
(3,995490)\end{array}$ \\
\hline Distance $_{i j}$ & & & $\begin{array}{c}98,58094^{* * *} \\
(3,556613)\end{array}$ & $\begin{array}{c}481,6207^{* * *} \\
(5,426649)\end{array}$ \\
\hline$G D P_{i}$ & & & $\begin{array}{c}125,6201^{* * * *} \\
(4,836443)\end{array}$ & $\begin{array}{c}98,19927^{* * *} \\
(5,003251)\end{array}$ \\
\hline Adj-R ${ }^{2}$ & 0,972061 & 0,951134 & 0,976939 & 0,985668 \\
\hline F-stat & 167,5071 & 33,84593 & 72,48826 & 117,0569 \\
\hline Cross-section $/ \mathrm{N}$ & $9 / 68$ & $9 / 28$ & $9 / 28$ & $9 / 28$ \\
\hline
\end{tabular}

Sumber: Output Eviews 11

Keterangan: nilai dalam ( ) merupakan t-stat

$* * *, * *, *$ signifikan pada $1 \%, 5 \%, 10 \%$

Internet users dan broadband yang menggambaran tingkat adopsi ICT terbukti berperan dalam memfasilitasi ekspor Indonesia ke negara mitra ASEAN. Peningkatan internet users di Indonesia sebanyak 1\% akan meningkatkan nilai ekspor Indonesia ke negara anggota ASEAN sebesar USD582,3 juta. Sesuai dengan penelitian Xing (2018), bahwa penerapan ICT dapat meningkatkan komunikasi antar negara yang melakukan perdagangan dimana dapat mendorong terciptanya efektivitas penyediaan, perdagangan, dan distrisbusi barang dan jasa. Selain itu, peningkatan jumlah pengguna internet juga menggambarkan bahwa masyarakat baik pelaku usaha ataupun calon pembeli semakin terhubung dengan pasar dan bagi pelaku usaha penggunaan internet semakin membuka peluang peningkatan penjualan. Hal ini juga sejalan dengan penelitian yang dilakukan oleh Chu dan Guo (2019) dan Ozcan (2018).

Di samping itu, broadband pada negara mitra di ASEAN juga berpengaruh positif pada nilai perdagangan Indonesia, dimana peningkatan penggunaan broadband sebanyak satu pengguna per 100 orang akan menyebabkan nilai ekspor Indonesia ke negara anggota ASEAN meningkat sebesar USD1.006,3 juta. Hal ini menggambarkan bahwa ketersediaan layanan broadband dapat menjadi stimu- 
lus pada meningkatnya permintaan barang dan jasa. Melalui layanan internet dengan kecepatan tinggi maka aktivitas bisnis dalam pasar intra-ASEAN dan global akan semakin meningkat. Akan tetapi, hasil studi juga menunjukkan bahwa peningkatan penggunaan broadband di Indonesia memberikan pengaruh negatif pada kinerja perdagangan. Pengaruh negatif tersebut dapat dijelaskan melalui tiga pendekatan yaitu pertama, Indonesia berada pada posisi kedua terendah untuk kecepatan fixed broadband dan kelima terendah pada kecepatan mobile broadband di ASEAN yaitu dengan rata-rata $4 \mathrm{Mbps}$. Data tersebut menunjukkan bahwa kualitas broadband Indonesia masih rendah sehingga belum mampu mendorong kinerja ekspor Indonesia secara signifikan. Kedua, karakteristik Indonesia sebagai negara kepulauan memungkinkan terjadinya kesenjangan layanan broadband yang belum merata. Hal ini tepat mengingat pembangunan jaringan Palapa Ring baru dimulai pada tahun 2015. Ketiga, layanan broadband yang ada utamanya dimanfaatakan untuk unduhan atau unggahan pemenuhan kebutuhan tersier.

Selain itu, Tabel 3. juga menunjukkan bahwa kegiatan $e$-commerce di negara mitra ASEAN berpengaruh signifikan pada nilai ekspor Indonesia. Ketika kegiatan e-commerce di negara anggota ASEAN meningkat sebanyak satu poin maka terjadi peningkatan nilai ekspor Indonesia sebesar USD1.908,7 juta, ceteris paribus. Sesuai dengan hasil studi Xing (2018) juga Chu dan Guo (2019) bahwa melalui e-commerce pelaku usaha individu ataupun masyarakat umum tidak lagi memiliki kendala waktu dan jarak dalam melakukan kegiatan perdagangan. Aktivitas perdagangan dan transaksi dapat dilakukan secara online serta pelaku usaha, juga memperoleh kesempatan untuk menjaring lebih banyak konsumen. Di sisi lain, kegiatan e-commerce di Indonesia belum memiliki dampak signifi- kan pada kinerja ekspor Indonesia. Beberapa indikasi menunjukkan bahwa (i) porsi pasar e-commerce B2B Indonesia di pasar ASEAN masih relatif kecil jika dibandingkan negara mitra regional seperti Singapura, Malaysia, dan Thailand; (ii) Indonesia hanya menghasilkan sekitar $4 \%$ perdagangan retail online (Competition and Consumer Commission of Singapore, 2017); (iii) pertumbuhan pemain e-commerce di sektor B2B tidak terlalu cepat; (iv) perdagangan B2C dan C2C masih mendominasi pasar e-commerce Indonesia; serta (v) terjadi ketidakseimbangan antara barang impor dan ekspor dalam pasar e-commerce.

Pada konteks lain, variabel makroekonomi (pangsa pasar, jarak ekonomi, dan PDB) berpengaruh positif pada peningkatan perdagangan Indonesia dengan mitra intra-ASEAN. Hasil estimasi mengkonfirmasi adanya hubungan positif dan signifikan pada taraf nyata $1 \%$ antara pangsa pasar dan perkembangan ekspor Indonesia pada negara mitra ASEAN. Ketika pangsa pasar meningkat sebesar 1\% akan menyebabkan nilai ekspor Indonesia ke negara anggota ASEAN meningkat sebesar USD1.947,3 juta, ceteris paribus. Pangsa pasar yang meningkat berpengarug pada peningkatan permintaan barang dan jasa sehingga memberi dampak baik pada pertumbuhan ekonomi, hal ini sejalan dengan studi yang dilakukan oleh Xing (2018).

Pertumbuhan PDB Indonesia memiliki hubungan positif signifikan terhadap nilai perdagangan Indonesia di pasar intra-ASEAN. Peningkatan $1 \%$ pada per- 
tumbuhan ekonomi Indonesia akan meningkatkan nilai perdagangan Indonesia sebesar USD98,2 juta, ceteris paribus. Mankiw (2007) menjelaskan bahwa PDB digunakan sebagai indikator dalam menentukan arah pembangunan dan tingkat pendapatan suatu negara, selain itu juga menggambarkan ukuran ekonomi suatu negara dan menunjukkan kemampuan potensial negara tersebut. Dari sisi Indonesia sebagai negara eksportir, peningkatan pertumbuhan ekonomi menyebabkan peningkatan produksi sehingga dapat meningkatkan penawaran yang selanjutnya mendorong peningkatan ekspor.

Jarak ekonomi antara Indonesia dengan negara mitra menggambarkan suatu hambatan dalam kegiatan perdagangan karena besarnya jarak ekonomi akan menyebabkan semakin tingginya biaya transportasi. Hasil estimasi dalam penelitian ini tidak sesuai dengan hipotesis dimana jarak ekonomi mempengaruhi nilai ekspor Indonesia secara positif signifikan pada taraf 1\%. Hasil estimasi menunjukkan bahwa peningkatan $1 \mathrm{~km}$ pada jarak ekonomi Indonesia dengan negara mitra akan meningkatkan nilai ekspor Indonesia sebesar USD80,5 juta, ceteris paribus. Menurut Disdier dan Head dalam Baier et al. (2017), jarak dalam estimasi gravitasi diperkirakan menurun seiring berkembangnya komunikasi dan teknologi. Kemungkinan variabel jarak dalam regresi gravitasi merupakan proksi dari beberapa determinan pada perdagangan internasional dan menggabungkan beberapa dampak dari perbaikan dalam komunikasi dan teknologi.

\section{Kesimpulan dan Saran}

Berdasarkan penelitian yang telah dilakukan, terdapat beberapa faktor yang memengaruhi nilai perdagangan Indonesia ke negara mitra ASEAN. Faktorfaktor tersebut adalah penggunaan ICT (pengguna internet di Indonesia dan penggunaan broadband di negara mitra) serta kegiatan e-commerce (transaksi B2B) berpengaruh positif pada nilai perdagangan Indonesia ke negara mitra ASEAN. Adapun penggunaan broadband di Indonesia berpengaruh negatif pada nilai perdagangan Indonesia ke negara mitra ASEAN. Selain itu, pertumbuhan ekonomi Indonesia, pangsa pasar, dan jarak ekonomi terbukti berpengaruh positif pada nilai perdagangan Indonesia ke mitra ASEAN. Secara keseluruhan, variabel ICT dan $e$-commerce memiliki pengaruh yang besar dibandingkan variabel lainnya terhadap peningkatan nilai perdagangan Indonesia ke negara mitra ASEAN.

Maka dari itu, perlu upaya serius untuk terus mendorong perkembangan ekonomi berbasis teknologi (e-commerce dan ekonomi digital) di Indonesia. Sejauh ini pemerintah telah membangun infrastruktur digital Palapa Ring serta menciptakan ekosistem perdagangan berbasis elektronik dengan menerbitkan Peraturan Pemerintah Nomor 80 Tahun 2019 tentang Perdagangan Melalui Sistem Elektronik (PP PMSE) dan Peraturan Pemerintah Nomor 71 Tahun 2019 tentang Penyelenggaraan Sistem dan Transaksi Elektronik (PP PSTE). Dari sisi perpajakan, pemerintah juga telah melakukan penyesuaian pajak pertambahan nilai (PPN) sebagai bentuk pengendalian impor yaitu sebesar $10 \%$. Hal ini juga dilakukan negara ASEAN lainnya seperti Malaysia (6\%), Singapura (7\%), dan 
Vietnam (5\%) untuk melindungi pasar domestiknya.

Ke depannya, diharapkan pemerintah dapat mengimplementasikan Peraturan Pemerintah terkait $e$-commerce dengan terus meningkatkan peran koordinasi pada setiap stakeholders. Pemberian insentif bagi pelaku usaha yang memanfaatkan ICT dan e-commerce juga perlu dilakukan untuk menstimulus pertumbuhan perdagangan. Bagi para pelaku usaha, diharapkan dapat memanfaatkan peluang perkembangan ekonomi digital melalui penggunaan fasilitas infrastruktur digital yang telah dibangun. Hal ini pada akhirnya bertujuan untuk mendorong perkembangan transaksi ekonomi digital yang selanjutnya dapat menjadi katalisator perekonomian nasional.

\section{Daftar Pustaka}

[1] Anandan, R., Sipahimalani, R., Saini, S., Aryasomayajula, S., \& Smittinet, W. (2018). e-Conomy SEA 2018: Southeast Asia's internet economy hits an inflection point. Think with Google. Diakses dari https: //www.thinkwithgoogle.com/intl/en-apac/tools-resources/research-studies / e-conomy-sea-2018-southeast-asias-internet-economy-hits-inflection-point/.

[2] Anandan, R., Sipahimalani, R., Saini, S., Bharadwaj, A., Beattie, R., Kim, D., \& Aryasomayajula, S. (2017, December). e-Conomy SEA Spotlight 2017: Unprecedented growth for Southeast Asia's \$50B internet economy. Diakses dari https: //www.thinkwithgoogle.com/intl/en-apac/tools-resources/research-studies/ e-conomy-sea-spotlight-2017-unprecedented-growth-southeast-asia-50-billioninternet-economy/.

[3] Andrés, L., Cuberes, D., Diouf, M., \& Serebrisky, T. (2010). The diffusion of the Internet: A cross-country analysis. Telecommunications Policy, 34(5-6), 323-340. doi: https:/ /doi.org/10.1016/j.telpol.2010.01.003.

[4] Arsyad, L. (1999). Ekonomi pembangunan (Edisi ke-4). Yogyakarta: STIE YKPN.

[5] ASEAN Secretariat. (2015). ASEAN economic community blueprint 2025. Jakarta: ASEAN Secretariat. Diakses dari https://asean.org/?static_post= asean-economic-community-blueprint-2025.

[6] ASEAN Secretariat. (2018). ASEAN statictical highlight 2018. Jakarta: ASEAN Secretariat. Diakses dari https://www.aseanstats.org/publication/ asean-statistical-highlights-2018/.

[7] Baier, S. L., Kerr, A., \& Yotov, Y. V. (2017). Gravity, distance, and international trade. CESifo Working Paper, 6357. Center for Economic Studies \& Ifo Institute. Diakses dari https:/ / www.cesifo.org/en/publikationen/2017/working-paper/ gravity-distance-and-international-trade.

[8] Bankole, F. O., Osei-Bryson, K. M., \& Brown, I. (2015). The impact of information and communications technology infrastructure and complementary factors on IntraAfrican trade. Information Technology for Development, 21(1: ICT in Africa: A Better Life for All, Part I), 12-28. doi: http:/ / dx.doi.org/10.1080/02681102.2013.832128.

[9] Bergstrand, J. H., \& Egger, P. (2013). Gravity equations and economic frictions in the world economy. In Bernhofen D., Falvey R., Greenaway D., \& Kreickemeier U. (eds) Palgrave handbook of international trade (pp. 532-570). Palgrave Macmillan, London. doi: https://doi.org/10.1007/978-0-230-30531-1_17.

[10] Burger, M., van Oort, F., \& Linders, G. J. (2009). On the specification of the Gravity 
Model of trade: Zeros, excess zeros and zero-inflated estimation. Spatial Economic Analysis, 4(2), 167-190. doi: https:/ /doi.org/10.1080/17421770902834327.

[11] Cette, G., Lopez, J., \& Noual, P. A. (2005). Investment in ICTs: an empirical analysis. Applied Economic Letters, 12(5), 309-312. doi: https://doi.org/10.1080/13504850500042280.

[12] Choi, C., \& Yi, M. H. (2009). The effect of the internet on economic growth: Evidence from cross-country panel data. Economics Letters, 105(1), 39-41. doi: https://doi.org/10.1016/j.econlet.2009.03.028.

[13] Chu, S. H., \& Guo, S. Y. (2019, July). Information and commnication technology and international trade: A case of China-ASEAN countries. In Proceedings of the 5th Annual International Conference on Management, Economics and Social Development (ICMESD 2019), [Advance in Economics, Business and Management Research, 87, pp. 206-211]. Atlantis Press. doi: https://dx.doi.org/10.2991/icmesd-19.2019.31.

[14] Competition and Consumer Commission of Singapore. (2017). Handbook on Competition and E-Commerce in ASEAN. Diakses dari https:/ / www.cccs.gov.sg/resources/ publications/other-publications/asean-ecommerce-handbook.

[15] Kemp, S. (2017, 16 February). Digital in Southeast Asia in 2017: Special Report. wearesocial.com. Diakses dari https://wearesocial.com/special-reports/ digital-southeast-asia-2017.

[16] Mankiw, N. G. (2007). Makroekonomi (Edisi ke-6). Jakarta: Erlangga.

[17] Ozcan, B. (2018). Information and communications technology (ICT) and international trade: evidence from Turkey. Eurasian Economic Review, 8(1), 93-113. doi: https://doi.org/10.1007/s40822-017-0077-x.

[18] Prasanti, T. A., Wuryandari, T., \& Rusgiyono, A. (2015). Aplikasi regresi data panel untuk pemodelan tingkat pengangguran terbuka kabupaten/kota di Provinsi Jawa Tengah. Jurnal Gaussian, 4(3), 687-696.

[19] Sen, A., Attavar, A., \& Jaiswal, R. (2016, 21 April). Internet: E-commerce in ASEAN Taking Off. Jefferies Franchise Note. Jefferies.

[20] Sutikno, B., Faruk, A., \& Dwipurwani, O. (2017). Penerapan regresi data panel komponen satu arah untuk menentukan faktor-faktor yang mempengaruhi Indeks Pembangunan Manusia. Jurnal Matematika Integratif, 13(1), 1-10. doi: https://doi.org/10.24198/jmi.v13.n1.11383.1-10.

[21] Xing, Z. (2018). The impacts of Information and Communications Technology (ICT) and E-commerce on bilateral trade flows. International Economics and Economic Policy, 15(3), 565-586. doi: https://doi.org/10.1007/s10368-017-0375-5. 